Committee will promote contaet and collaboration wherever possible between centres of industrial research or institutions and research workers; and facilitate co-operative research within British industry, with special reference to the needs of smallscale industries. Information on research questions will be provided by creating a liaison with appropriate reference libraries and technical and scientific institutions; and attention directed to the publications of professional, technical and scientific institutions, assistance being given where necessary in their distribution. The Committee will promote the com pilation of general information on industrial research, particulars of organizations and the facilities available; and provide from time to time information for press and public on the achiovements of British industrial research.

\section{A Medical Nobel Institute in Sweden}

ThE Royal Caroline Institute (Kungl. Karolinska Medico-Kirurgiska Institutet), which is the medical school of Stockholm-the University of Stockholm (Stockholms Högskola) having no medical facultyand is in charge of the medical Nobel Fund, has decided to build a Medical Nobel Institute for research in the three theoretical disciplines, anatomy, biochemistry and physiology. The new Institute will consist of three departments in one building to be erected on the premises of the new medical centre at Norrbacka in the north-west region of the city. The Biochemical Nobel Institute was founded in 1937 and is directed by Prof. Hugo Theorell. The physiological department will be a Neurophysiological Research Laboratory privately endowed in 1940 for Prof. Ragnar Granit, who will also be in charge of the new institute. The anatomical department will be associated with a new chair in cell research to be created for Dr. Torbjörn Caspersson.

Relation of Employment to an Economic System A MeMorandum "Employment After the War" submitted by the Social Credit Co-ordinating Committee, Greno House, Swinton, Mexborough, Yorks (3d.), for the consideration of Sir William Beveridge, argues that full employment is not the right objective of an efficient economic system. The essential function of industry is to supply the goods and services which people require, and it is no part of the function of industry to deprive people of leisure or to keep them occupied in order to reduce the difficulties of Government. Social security, with freedom, can only be realized if we recognize, first, that production is no longer a major problem : the problem to-day is that of distributing the abundance of goods that can be produced. Further, money is the social mechanism for the distribution of goods : thirdly, science has so well succeeded in harnessing solar energy to the service of man that the need for human labour in industry has decreased and will continue to decrease progressively ; and, lastly, the true purpose of employment is to provide goods and services for our use and not to provide people with incomes. The memorandum then briefly summarizes the Sorial Credit proposals : a national credit office; the institution of a scientific price discount; and the distribution of national dividends. These proposals are designed to deal with what is described as the real problem, which is not how to share out the hours of work available, but how to remove from unemployment its ugly concomitants of frustration and a low standard of living.

\section{Institute of Medical Laboratory Technclegy}

The Institute of Medical Laboratory Technology, which was incorporated in November 1942, with registered offices at 308 Dewsbury Road, Wakefield, Yorks, has issued a memorandum and articles of association. All scientific workers will commend the objects of this Institute. As its secretary, Mr. S. J. Denyer, says, its formation "indicates the desire of the laboratory technician to meet the increased demands of his profession and to acquire the professional status already accorded to other -scientific workers". The Institute incorporates the Pathological and Bacteriological Laboratory Assistants Association and takes over the publication of the Laboratory Journal and the Monthly Bulletin previously issued by that Association. To meet modern demands, the Institute requires an approved educational standard as one qualification for membership. Ordinary members or associates of the Pathological and Bacteriological Laboratory Assistants Association may become ordinary members of the Institute by application, but others must be elected; they must be not less than twenty years old, they must have had not less than three years experience in an approved pathological, bacteriological or chemical pathology laboratory and must pass an intermediate examination controlled by the Institute. Candidates for the associateship of the Institute must either hold the certificate of the parent Association in one subject or must, after completing five years training in an approved laboratory and attaining the age of twentytwo, pass the Institute's final examination in one subject. Fellows must have been registered members of the parent Association for ten or more years, or must hold that Association's certificates in two or more subjects ; in either case they can become fellows by application. Others may be elected to fellowship if they are already associates of the Institute and either pass the Institute's final examination in two or more subjects or submit an acceptable thesis, and have also been associates of the Institute for ten or more years, inclusive of previous registered membership of the parent Association.

It will be clear that the associateship and the fellowship of the new Institute are not lightly acquired; and ordinary membership must itself command respect. This will give to the technicians in the laboratories concerned the status which they deserve, for without their willing help, their interest in the work and their devotion to it, many great discoveries would not have been made. It is good to know that members of the medical profession give willingly of their time to help to train these essential workers; every other kind of scientific worker will wish to do the same.

\section{Smithsonian Institution: Annual Report}

THE report of the Smithsonian Institution for the year ended June 30, 1942 (Washington, D.C. : Gov. Printing Office. 1.50 dollars), includes the report of the secretary together with the reports on the United States National Museum, the Bureau of American Ethnology, the International Exchange Service, the National Zoological Park, the Astrophysical Observatory, and the Division of Radiation and Organisms, together with a general appendix on the lines of that in the previous report. Referring to the war activities of the Institution, the secretary's report states that a War Committee has been constituted and a detailed roster prepared of the scientific staff, numbering 